Nur Rahma Syaadilah Arif : 70200119109

\title{
PENGUATAN KADER KESEHATAN MELALUI EDUKASI GIZI DALAM MENGATASI ANEMIA PADA IBU HAMIL
}

\section{PENDAHULUAN}

Anemia pada ibu hamil sangat berpengaruh terhadap kualitas manusia yang akan dilahirkan dan kualitas sumber daya manusia (SDM) generasi yang akan datang. Selain itu, anemia pada ibu hamil dapat meningkatkan kejadian abortus, prematus, berat badan lahir rendah (BBLR), serta dapat menyebabkan kematian pada ibu hamil pada waktu dan sesudah melahirkan. Wanita hamil sangat sulit untuk mendapatkan cukup zat besi walaupun telah mengkonsumsi makanan yang tinggi zat besi setiap hari (Klein dan Thomson, 2008). Hal tersebut disebabkan karena zat besi adalah salah satu nutrient yang tidak dapat diperoleh dalam jumlah adekuat dari makanan yang dikonsumsi selama hamil (Bobak, dkk, 2005) dalam Nurhayati dkk (2014).

Anemia merupakan masalah yang dialami oleh $41,8 \%$ ibu hamil di dunia. Sekitar setengah dari kejadian anemia disebabkan karena defisiensi besi. Adapun prevalensi anemia pada ibu hamil di dunia yaitu diperkirakan Afrika sebesar 57,1\%, Asia 48,2\%, Eropa 25,1\%, dan Amerika 24,1\% (WHO 2015).

Prevalensi anemia pada ibu hamil di indonesia menurut Riset Kesehatan Dasar (Riskesdas) tahun 2013 sekitar 37,1\% yaitu ibu hamil dengan kadar Hb kurang dari 11,0 gram/dl, dengan proporsi yang hampir sama antara di kawasan perkotaan $(36,4 \%)$ dan perdesaan (37,8\%) Infondatin Gizi (2015).

Data Dinas Kesehatan provinsi Sulawesi Selatan menunjukkan bahwa terdapat ibu hamil dengar kadar hemoglobin 8-11 mg/dl sebesar 98,49\% dan ibu hamil dengan kadar hemoglobin $<8 \mathrm{mg} / \mathrm{dl}$ sebesar 1,15\% (Data Binkesmas, Dinas Kesehatan Provinsi Sulawesi Selatan, 2015). Di kota Makassar terdapat 46 puskesmas menurut data dari dinas kesehatan provinsi sulsel tahun 2016 pemberian kablet Fe1 (30 kablet) 100\% dan fe(90 kablet) 95,8\%. Ini menunjukkan bahwa pemerintah Sulawesi Selatan telah melakukan upaya untuk mengurangi prevalensi anemia ibu hamil. Namun sampai sekarang permasalahan anemia ibu hamil belum sepenuhnya dapat teratasi (Dinas Kesehatan Kota Makassar, 2015). 
Kurangnya pemahaman masyarakat terhadap penyakit anemia pada ibu hamil menjadi satu permasalahan dalam pemberian dukungan terhadap klien anemia pada ibu hamil. Hasil wawancara awal dengan beberapa kader kesehatan, meskipun sudah dilakukan penyuluhan tentang anemia pada ibu hamil belum sepenuhnya tersosialisasikan baik kepada kader kesehatan maupun masyarakat. Oleh karena itu perlu adanya sosialisasi untuk peningkatan pengetahuan dan pemahaman masyarakat tentang anemia pada ibu hamil agar kesadaran tentang bahaya anemia pada ibu hamil dapat menjadi motivasi dalam melakukan skrining atau deteksi dini terjadinya anemia dengan melakukan pemeriksaan kadar $\mathrm{Hb}$ dan meningkatkan upaya untuk pencegahan dan penanganan anemia pada ibu hamil di masyarakat. Upaya pemberdayaan masyarakat merupakan salah satu upaya yang dapat digunakan sebagai strategi promosi kesehatan baik dalam level primer, sekunder maupun tersier sesuai dengan piagam ottawa carter (Kemenkes, 2017).

\section{STATUS GIZI IBU HAMIL}

Status gizi dan kesehatan ibu pada masa pra-hamil, saat kehamilan dan saat menyusui merupakan periode yang sangat penting yang menentukan kualitas sumber daya manusia nantinya. Periode ini dikenal dengan periode 1000 Hari Pertama Kehidupan (HPK) manusia yang dihitung dari 270 hari selama kehamilan dan 730 hari pada kehidupan pertama bayi yang dilahirkan (sampai anak berusia 2 tahun). Masa ini merupakan periode sensitif karena akibat kekurangan asupan gizi yang ditimbulkan terhadap bayi pada masa ini akan bersifat permanen dan tidak dapat diperbaiki. Dampak tersebut tidak hanya pada pertumbuhan fisik, tetapi juga pada perkembangan mental dan kecerdasannya, yang pada usia dewasa terlihat dari ukuran fisik yang tidak optimal serta kualitas kerja yang tidak kompetitif sehingga produktivitas ekonomi menjadi rendah.

Nutrisi selama kehamilan adalah salah satu faktor penting dalam pembentukan janin. Pola makan yang baik akan cukup menyediakan gizi yang dibutuhkan untuk kesehatan selama kehamilan dan mengurangi risiko lahirnya baayi cacat. Selain itu makanan yang baik akan membantu sistem pertahanan tubuh ibu hamil terhadap terjadinya infeksi. Makanan yang baik juga akan melindungi ibu hamil dari akibat buruk zat-zat yang mungkin ditemui seperti obat-obatan, toksin, dan polutan. Asupan makanan selama hamil berbeda dengan asupan sebelum masa kehamilan untuk memenuhi kebutuhan ibu dan janin, berdasarkan Angka Kecukupan Gizi (AKG). 
Gizi ibu hamil adalah makanan atau zat gizi (baik makro maupun mikro) yang dibutuhkan oleh seorang ibu hamil baik padaa trimester I, trimester II dan trimester III serta harus mencukupi jumlah yang dibutuhkan, mutu yang dapat dipenuhi dari kebutuhan seharihari sehingga janin yang dikandungnya dapat tumbuh dengan baik serta tidak memiliki gangguan. Ibu yang hamil harus memiliki gizi yang cukup, karena gizi yang didapat akan digunakan untuk dirinya dan janinnya. Seorang ibu yang tidak memiliki ataupun kekurangan gizi selama awal kehamilan, maka bayi yaang dikandungnya akan menderit kekurangan gizi. Selama kehamilan, secara fisiologis ibu hamil akan mengalami perubahan. Perubahan yang dialami seorang ibu hamil meliputi perubahan sistem reproduksi, sistem perkemihan, sistem pencernaan, sirkulasi darah, kulit, metabolisme, sistem pernafasan, dan penambahan berat badan. Perubahan fisiologis pada ibu hamil akan mempengaruhi perubahan kebutuhan gizi ibu hamil. (Simbolon, 2018)

Perubahan kebutuhan gizi ibu hamil tergantung dari kondisi kondisi kesehatan ibu. Kusmiyati (2009) mengungkapkan dasar pengaturan gizi ibu hamil adalah adanya penyesuaian selama kehamilan yaitu, sebagai berikut:

1. Peningkatan basal metabolisme dan kebutuhan kalori. Metabolisme basal pada masa 4 bulan pertama mengalami peningkatan kemudian menurun $20-25 \%$ pada 20 minggu terakhir. 2. Perubahan fungsi alat pencernaan karena perubahan hormonal, peningkatan HCG, esterogen, progesteron menimbulkan berbagai perubahan seperti mual muntah, motilitas lambung sehingga penyerapan makanan lebih lama, peningkatan absorbsi nutrien, dan motilitas usus sehingga timbul masalah obstipasi.

3. Peningkatan fungsi ginjal sehingga banyak cairan yang dieksresi pada pertengahan kehamilan dan sedikit cairan diekskresi pada bulan-bulan terakhir kehamilan.

4. Peningkatan volume dan plasma daraah hingga 50\% jumlah erytrosit 20-30\% sehingga terjadi penurunan hemodilusi dan konsentrasi hemoglobin.

Kebutuhan gizi pada ibu hamil yang terpenuhi dalam makanan sehari-hari akan berpengaruh pada tumbuhan dan perkembangan bayi, janin dalam kandungan dapat tumbuh dengan baik serta tidak mengalami gangguan dan masalah. Asupan makanan yang dikonsumsi oleh ibu hamil berguna untuk pertumbuhan dan perekmbangan janin, mengganti sel-sel tubuh yang rusak atau mati, sumber tenaga, mengatur suhu tubuh dan cadangan makanan. Kebutuhan selama hamil yang berbeda-beda untuk setiap individu dan juga dipengaruhi oleh riwayat kesehatan dan status gizi ibu sebelumnya (Simbolon, 2018). 
Prevalensi anemia meningkat sebesar 15-20\% dengan kehamilan yang disebabkan karena sebelum wanita mengalami kehamilan mereka telah jatuh pada keadaan anemia. Kekurangan gizi pada ibu hamil dan perhatian yang kurang merupakan predisposisi anemia ibu hamil di indonesia. Anemia akan meningkat resiko terjadi kematian ibu 3,7 kali lebih tinggi jika dibandingkan ibu yang tidak anemia (Lubiz, Z. 2003, dan Supariasa, Bakrie, Fajar, 2002). Masalah gizi yang dialami ibu hamil saat ini adalah gizi kurang seperti Kurang Energi Kronis (KEK) dan anemia gizi. Status gizi ibu hamil dapat diukur dengan Lingkar Lengan Atas (LILA) $<23,5 \mathrm{~cm}$ untuk LILA yang berisiko dan $\geq 23,5 \mathrm{~cm}$ untuk LILA tidak berisiko (Lubiz, Z.2003).

Status gizi ibu hamil bisa diketahui dengan mengukur ukuran LILA, bila $<23,5 \mathrm{~cm}$ maka ibu hamil termasuk KEK, ini berarti ibu sudah mengalami keadaan kurang gizi dalam jangka waktu yang lama, bila ini terjadi maka kebutuhan nutrisi untuk proses tumbuh kembang janin makin terlambat, akibatnya bayi yang dilahirkan menderita BBLR (Antarini, Y. 2003). Lingkar lengan atas dan kadar Hemoglobin ibu hamil mempunyai peranan penting dalam pertumbuhan dan perkembangan janin. Konsumsi makanan yang kurang dan penyakit yang dialami ibu hamil akan berakibat buruk terhadap perkembangan atau pertumbuhan janin. Pada ibu hamil diperlukan tambahan konsumsi protein untuk pembentukan sel darah merah yang berguna untuk membantu pertumbuhan janin.

\section{ANEMIA PADA KEHAMILAN}

Anemia kehamilan didefinisikan WHO sebagai kadar hemoglobin kurang dari 11g/dl atau hematokrit kurang dari $33 \%$ pada setiap waktu pada kehamilan (Sharma and Meenakshi, 2010). Definisi anemia kehamilan oleh WHO ini berbeda dengan definisi oleh Center for Disease Control and Prevention (CDC). Definisi anemia kehamilan oleh CDC (2012) mempertimbangkan hemodilusi yang normal terjadi dalam kehamilan di mana kadar hemoglobin kurang dari $11 \mathrm{~g} / \mathrm{dl}$ pada trimester pertama dan ketiga, dan kurang dari 10,5 g/dl pada trimester kedua (Creasi et al, 2009). Dengan adanya batas anemia yang berbeda pada trimester II dan lainnya, maka setiap hasil pemeriksaan perlu melihat standar batas anemia yang telah ditentukan.

Menurut Proverawati (2011) anemia merupakan suatu kumpulan gejala yang disebabkan oleh bermacam-macam penyebab. Terjadinya anemia karena adanya beberapa faktor yang saling berkaitan. Pada dasarnya anemia disebabkan oleh karena gangguan pembentukan eritrosit oleh sumsum tulang belakang, kehilangan darah keluar tubuh 
(pendarahan), dan proses penghancuran erirosit dalam tubuh sebelum waktunya (hemolisis), faktor nutrisi, infeksi, dan pengaruh genetik (Masukume et al, 2015). Penyebab anemia yang lain antara lain pendarahan misalnya ulkus, gastritis, tumor saluran pencernaan, malabsorpsi, kecelakaan yang mengakibatkan kehilangan banyak darah, malabsorpsi besi, dan menoragia (menstruasi berlebihan), defisiensi besi, asam folat, infeksi HIV, gangguan struktur hemoglobin seperti thalassemia (Masukume et al, 2015). Pada ibu hamil yang anemia harus diketahui secara pasti penyebab anemianya sehingga dapat diberikan intervensi yang tepat.

\section{PENYEBAB, EDUKASI PENCEGAHAN DAN PENANGANAN ANEMIA PADA IBU HAMIL}

Anemia adalah suatu keadaan dimana tubuh kekurangan sel darah merah (eritrosit), eritrosit sendiri mengandung hemoglobin yang mempunyai afinitas terhadap oksigen dan membawa oksigen ke seluruh tubuh (Proverawati \& Atikah, 2013). Menurut Prawiroharjo (2010) anemia merupakan suatu keadaan adanya penurunan kadar hemoglobin, hematokrin dan jumlah eritrosit dibawah normal. Pada penderita anemia, lebih sering disebut kurang darah, kadar sel darah merah (hemoglobin/Hb) dibawah nilai normal.

Penyebabnya bisa karena kurangnya zat besi, asam folat, dan vitamin B12. Tetapi yang sering terjadi adalah anemia karena kekurangan zat besi. Anemia menjadi masalah terutama pada wanita usia reproduksi karena dapat menimbulkan kelelahan, badan lemah, penurunan kemampuan atau produktifitas kerja. Menurut Simanjuntak dalam Nurjanah (2012) di Indonesia 70\% ibu hamil mengalami anemia dikarenakan jarak kehamilan dan persalinan yang terlalu dekat, pendidikan rendah dan sosial ekonomi yang rendah. Anemia pada ibu hamil erat kaitannya dengan fisiologi kehamilan dimana tubuh mengalami perubahan jumlah darah meningkat dalam tubuh 20-30\% sehingga kebutuhan zat besi dan vitamin meningkat untuk pembuatan hemoglobin $(\mathrm{Hb})$ selain itu ibu hamil juga harus berbagi darah dengan bayinya sehingga kebutuhan darah 30\% lebih banyak dibanding sebelum hamil (Noversiti, 2012).

Salah satu upaya pencegahan dan penanganan anemia pada ibu hamil diantaranya dengan meningkatkan pengetahuan dan merubah sikap menjadi positif melalui edukasi tentang kebutuhan gizi selama kehamilan, periksa kehamilan minimal 4 kali selama hamil, pemberian zat besi 90 tablet, cek Hb semester I dan III, segera memeriksakan diri jika ada keluhan yang tidak biasa, penyediaan makanan yang sesuai kebutuhan ibu hamil, meningkatkan pengetahuan dan perilaku ibu hamil maupun keluarga dalam memilih, 
mengolah dan menyajikan makanan serta meningkatkan kualitas pelayanan kesehatan dan gizi (Solehati, Sari, Lukman, \& Kosasih, 2018).

Pengaruh edukasi pencegahan dan penanganan anemia terhadap pengetahuan ibu hamil di Puskesmas Haurpanggung dapat dilihat dari hasil uji test t-paired yang dilakukan pada 37 orang responden dengan nilai rata-rata pengetahuan sebelum dilakukan edukasi 51,97 dengan standar deviasi 14,55 sedangkan sesudah edukasi rata-rata 64,03 dengan standar deviasi 10,42 dan terdapat perbedaan pengetahuan sebelum dan sesudah edukasi sebesar 8,06 dengan P-Value 0,000. Nilai rata-rata sikap responden tentang pencegahan dan penanganan anemia pada ibu hamil sebelum edukasi 50,54 dengan standar deviasi 29,72 sedangkan sesudah edukasi rata-rata sikap 69,73 dengan standar deviasi 13,64 dan terdapat perbedaan sikap sebelum dan sesudah edukasi sebesar 19,19 dengan P-Value 0,000. Dimana tujuan dari edukasi ini adalah untuk meningkatkan pengetahuan dan sikap ibu hamil tentang pencegahan dan penanganan anemia pada ibu hamil, dengan meningkatnya pengetahuan ditunjang dengan sikap yang mendukung diharapkan ibu hamil akan secara sadar melakukan pencegahan dan penanganan anemia.

\section{DAMPAK ANEMIA PADA IBU HAMIL DAN JANIN}

Anemia ringan pada ibu hamil tidak secara langsung berdampak buruk pada kehamilan dan persalinan kecuali cadangan besi dalam tubuh ibu semakin berkurang sehingga anemia berubah menjadi tingkat sedang atau berat. Anemia sedang menyebabkan kelelahan, kekurangan energi, keletihan, dan kinerja yang buruk. Anemia berat berhubungan dengan hasil kehamilan yang buruk, misalnya terjadi palpitasi, takikardi, sesak napas, meningkatkan curah jantung yang dapat ngakibatkan dekompensasi dan gagal jantung yang berakibat fatal, peningkatan insiden persalinan preterm, preeklamsia, dan sepsis (Milman, 2015). Anemia selama kehamilan memunyai implikasi yang negatif pada janin karena anemia dikaitkan dengan kerusakan perkembangan otak, BBLR komplikasi bayi lahir preterm, KMK (Kecil Masa Kehamilan), dan IUGR (Masukume et al, 2015; Milman, 2015; Viteri, 2011).

\section{KANDUNGAN ZAT GIZI BISKUIT UBI JALAR UNGU DAN ROTI RUMPUT LAUT LAWI-LAWI SUBTITUSI TEMPE SEBAGAI PERBAIKAN GIZI PADA IBU HAMIL}

Ubi jalar (Ipomoea batatas) meru-pakan komoditas sumber karbohidrat uta-ma, setelah padi, jagung, dan ubi kayu, ser-ta mempunyai peranan penting dalam penyediaan bahan pangan, bahan baku in-dustri maupun pakan ternak. Sebagai sum-ber karbohidrat, ubi 
jalar memiliki peluang sebagai substitusi bahan pangan utama, se-hingga bila diterapkan mempunyai peran penting dalam upaya penganekaragaman pangan dan dapat diproses menjadi aneka ragam produk yang mampu mendorong pengembangan agro-industri dalam diversi-fikasi pangan (Zuaraida dan Supriati, 2011).

Produktivitas ubi jalar di Indonesia pada tahun 2014 sebanyak 152,00 ku/ha meningkat 5,61\% pada t (Aguscik, 2019) (Syarfaini S. A., 2019) tahun 2015 sebesar 160,53 ku/ha (Badan Pusat Statistik, 2015). Tercatat pada tahun 2015 produksi ubi jalar di Provinsi Sulawesi Selatan sebesar 71.677 ton terjadi kenaikan sebesar 4.035 ton dari tahun 2014 dengan produksi sebesar 67.642 ton. Penghasil ubi jalar terbesar di Sulawesi Selatan ada di Kabupaten Bone dengan produksi sebesar 21.688 ton, disusul Kabu-paten Gowa sebesar 6.033 ton, Kabupaten Takalar 5.731 ton dan Kabupaten Maros sebesar 4.612 ton (Dinas Pertanian Sulawesi Selatan, 2015).

Hasil penelitian analisis vitamin C pada varietas ubi jalar yang umbinya berwarna ungu memiliki kandungan vitamin C paling besar yaitu 0,0177 mg/100 gram (Nathania dkk, 2013). Ubi ungu mengandung pigmen antosianin yang lebih tinggi daripada varietas lain. Warna ungu yang kuat menunjukkan tingginya kadar antioksidan dan antosianin didalamnya. Kandungan protein di dalam ubi jalar ungu lebih tinggi daripada ubi jalar kuning 0,77\% (Winarti, 2010). Kandungan betakaroten dan vitamin C bermanfaat sebagai antioksidan pencegah kanker dan beragam penyakit kardiovaskuler. Kandungan serat dan pektin di dalam ubi jalar sangat baik untuk mencegah ganguan pencernaan seperti wasir, sembelit hingga kanker kolon (Sutomo, 2007).

Dalam hal ini, potensi sumber daya alam khususnya pemanfaatan ubi jalar ungu, maka pada penelitian ini peneliti akan membuat diversifikasi pangan lokal yaitu biskuit ubi jalar ungu dengan menganalisis kandungan zat gizi karbohidrat, protein, lemak, zat besi (Fe), vitamin C (Asam Askorbat) dan uji arganoleptik guna memberikan alternatif perbaikan gizi pada masyarakat. Dengan adanya kandungan karbohidrat pada biskuit ubi jalar ungu, maka biskuit tersebut dapat digunakan sebagai alternatif dan makanan tambahan meskipun memiliki kandungan karbohidrat yang tergolong rendah. Namun dapat kita penuhi dengan konsumsi makanan lainnya karena fungsi utama karbohidrat sebagai zat sumber energi (Amriani, 2017).

Sedangkan produksi rumput laut nasional pada jenis lawi-lawi (ceulerpa $s p$ ) dalam kurun 2011-2015 menunjukkan kenaikan dengan rata-rata pertumbuhan 22,2 \%. Pada 2015, 
volume produksi rumput laut nasional seki-tar 11,2 juta ton dengan nilai Rp 13,2 tril-iun atau naik 9,8\% dari volume produksi tahun sebelumnya sebanyak 10,2 juta ton (Kementrian Kelautan dan Perikanan, 2016). Rumput laut lawi-lawi memiliki kandungan gizi yang cukup tinggi sebagai sumber protein nabati maupun mineral. Jenis rumput laut ini, mengandung protein $17-27 \%$, lemak $0,08-1,9 \%$, karbohidrat $39-50 \%$, serat 1,3 -12,4\%, dan kadar abu 8,15 - 16,9\% serta kadar air yang tinggi 80 - 90\% (Verlaque et al, 2003 dalam Burha-nuddin, 2014: 8). Tempe merupakan salah satu bahan makanan yang tepat. Setiap 100 gram tempe mengandung protein 20,8 gram, lemak 8,8 gram, serat 1,4 gram, kalsium $155 \mathrm{mg}$, fosfor 326 mg, zat besi 4 mg, vitamin B1 0,19 mg,dan karoten $34 \mu \mathrm{g}$ (Bastian, dkk, 2013: 5).

Pemanfaatan rumput laut dan tempe dapat dimaksimalkan dengan diverifikasi produk olahan yang merupakan salah satu upaya untuk meningkatkan daya guna dan nilai ekonomis dari rumput laut. Salah satu jenis produk makanan yang saat ini sering dikonsumsi di masyarakat mulai dari anak-anak hingga dewasa adalah roti.

Nilai energi rumput laut Ceulerpa racemosa kebanyakan di kontribusi oleh karbohidrat dan protein karena nilai total lipid rendah $(2,06 \%$ DW). Oleh karena itu, alga ini cocok sebagai makanan diet untuk menurunkan obesitas (Mukarramah et al., 2017).

\section{HUBUNGAN TINGKAT PENGETAHUAN IBU HAMIL TENTANG ANEMIA DENGAN KEJADIAN ANEMIA PADA IBU HAMIL TRIMESTER III}

Masyarakat mempunyai peranan terutama dalam pemantauan wilayah setempat ibu dan anak (PWS-KIA), dimana salah satu indikatornya adalah peningkatan deteksi dini resiko tinggi/komplikasi kebidanan oleh masyarakat. Upaya lain dalam partisipasi masyarakat yaitu meningkatkan "gerakan sayang ibu" yang diwujudkan dengan beberapa program yang dilakukan dan dikelola oleh masyarakat seperti desa siaga (Manuaba, 2008). Desa siaga yaitu desa yang penduduknya memiliki kesiapan sumber daya dan kemampuan serta kemauan untuk mencegah serta mengatasi masalah kesehatan, bencana, kegawatdaruratan, dan kesehatan secara mandiri. (Kepmenkes, 2010)

Berdasarkan studi pendahuluan yang dilakukan pada bulan Februari 2016 dengan melihat data sekunder dari tahun 2014 tentang anemia pada ibu hamil yaitu ibu hamil yang melakukan pemeriksaan pemeriksaan $\mathrm{Hb}$ sebanyak 670 yang mengalami anemia sebanyak $248(37,01 \%)$, dan pada tahun 2015 ibu hamil yang memeriksakan Hb sebanyak 925 dan yang mengalami anemia sebanyak 346 (37,40 \%), trimester I 1,73\%, Trimester II 39,30\%, dan trimester III sebanyak 57,22\% ibu hamil yamg mengalami anemia.

Berdasarkan uji statistik nonparametrik menggunakan uji Kendall-Tau dengan taraf kesalahan 5\% dan tingkat kepercayaan 95\%, didapatkan nilai signifikansi sebesar 0,006. 
Karena nilai signifikansi $<$ 0,05 dengan demikian hasil tersebut menunjukkan bahwa ada hubungan antara tingkat pengetahuan tentang anemia dengan kejadian anemia pada ibu hamil. Hal ini juga menunjukkan hasil nilai koefisien korelasi yaitu Pengetahuan atau kognitif merupakan domain yang sangat penting untuk terbentuknya tindakan seseorang (ovent behavior). Dari pengalaman dan penelitian ternyata perilaku yang disadari oleh pengetahuan akan lebih bertahan lama dari pada perilaku yang tidak disadari oleh pengetahuan (Notoatmodjo, 2010). Tingkat pengetahuan salah satunya dapat diketahui melalui informasi, seseorang yang mempunyai sumber informasi yang lebih banyak akan mempunyai pengetahuan yang lebih luas. Dalam penelitian ini dari 61 responden sebanyak 25 orang $(41 \%)$ memiliki pengetahuan baik, pengetahuan seseorang biasanya diperoleh dari pengalaman yang berasal dari berbagai sumber misalnya petugas kesehatan, media masa, media elektronik, buku petunjuk kesehatan, media poster, kerabat dekat dan sebagainya (Manuaba, 2010)

\section{PEMBERDAYAAN MASYARAKAT DALAM UPAYA PENCEGAHAN ANEMIA}

Keterlibatan masyarakat sebagai komunitas tempat tinggal ibu hamil tentunya sangat diperlukan dalam upaya pencegahan dan penanganan anemia pada ibu hamil, salah satu upaya untuk meningkatkan kualitas hidup ibu hamil adalah terbentuknya satu dukungan dari masyarakat. Dengan demikian, kontribusi keluarga sebagai pemberi perawatan dan penguatan kapasitas kader kesehatan merupakan hal yang sangat penting. Kurang terpaparnya masyarakat dan kader kesehatan mengenai anemia pada ibu hamil diprediksi menjadi penyebab kurangnya dukungan sosial terhadap klien dengan anemia pada ibu hamil. Dukungan tersebut akan muncul seiring dengan meningkatnya pengetahuan dan sikap masyarakat terhadap masalah anemia pada ibu hamil.

Oleh karena itu, perlu dilakukan suatu kegiatan untuk meningkatkan pemberdayaan masyarakat melalui kader kesehatan dalam mengenal, mencegah dan menangani anemia pada ibu hamil sehingga dukungan sosial berbasis masyarakat dapat ditingkatkan. Melalui upaya keterlibatan dan pemberdayaan masyarakat (kader kesehatan) ini diharapkan dukungan dalam upaya pencegahan dan penanganan anemia pada ibu hamil dapat meningkat (Sukmawati, 2018). 


\section{DAFTAR PUSTAKA}

Aguscik, R. (2019). Pengaruh Status Gizi Terhadap Kejadian Anemia Pada Ibu Hamil Di Daerah Endemik Malaria Kota Bengkulu. (JPP) Jurnal Kesehatan Poltekkes Palembang, 97-100.

Amriani, A. (2017). Analisis Kandungan Zat Gizi Biskuit Ubi Jalar Ungu (Ipomoea Bantatas L. Poiret) sebagai Alternatif Perbaikan Gizi di Masyarakat (Doctoral dissertation, Universitas Islam Negeri Alauddin Makassar).

Kafiyanti, N., Muhartati, M., \& Kasjono, H. S. (2016). Hubungan Tingkat Pengetahuan Ibu Hamil Tentang Anemia Dengan Kejadian Anemia Pada Ibu Hamil Trimester III di Puskesmas Jetis Kota Yogyakarta.

Masukume G, Ali SK, Louise CK, Philip NB, and Gill N. (2015). Risk Factors and Birth Outcomes of Anaemia in Early Pregnancy in a Nulliparous Cohort. PLOS ONE 10 (4).

Mukarramah dkk. Low Fat High Protein Sosis Berbahan Dasar Lawi-Lawi (Caulerpa racemosa) sebagai Inovasi Kuliner Sehat Khas Makassar dan Makanan Alternatif bagi Anak Penderita Obesitas. Makassar: Hasanuddin Student Journal Vol. I No. 1, 2017.

Proverawati, A. (2011). Anemia dan Anemia Kehamilan. Yogyakarta: Nuha Medika.

Setyaningtyas, S. W., Rochmah, T. N., Mahmudiono, T., Hidayah, S., \& Adhela, Y. D. (2020). Gambaran Pengetahuan, Sikap, dan Perilaku Kader Palang Merah Remaja (PMR) di SMAN 2 Lamongan Terhadap Program Suplementasi Tablet Tambah Darah. Amerta Nutrition, 4(3), 213-217.

Sukmawati, L. M. (2019). Pengaruh Edukasi Pencegahan dan Penanganan Anemia Terhadap Pengetahuan dan Sikap Ibu Hamil. Jurnal Keperawatan BSI, 42-47.

Sukmawati, S., Mamuroh, L., \& Nurhakim, F. (2018). Pemberdayaan Masyarakat Dalam Upaya Pencegahan Dan Penanganan Anemia Pada Ibu Hamil Di Puskesmas Haurpanggung. Jurnal Pengabdian Kepada Masyarakat, 2(9), 804-807.

Suparni, F. R. (2020). Pengaruh Pemberian Ubi Jalar Ungu (Ipomoea Batatas) Terhadap Peningkatan Lingkar Lengan Atas Ibu Hamil Dengan Kekurangan Energi Kronis Di 
Wilayah Puskesmas Kedungwuni II Kecamatan Kedungwuni Kabupaten Pekalongan Tahun 2018. Jurnal Ilmiah Kesehatan Keperawatan, 62-67.

Syarfaini, D. S. (2019). Analisis Kandungan Zat Gizi Roti Rumput Laut Lawi-Lawi (Ceulerpa racemosa) Subtitusi Tempe Sebagai Alternatif Perbaikan Gizi Masyarakat. Al-Shihah : Public Health Science Journal, 94-106.

Syarfaini, M. F. (2017). Analisis Kandungan Zat Gizi Biskuit Ubi Jalar Ungu (Ipomoea batatas L. Poiret) Sebagai Alternatif Perbaikan Gizi Di Masyarakat. Al-Shihah : Public Health Science Journal, 138-152.

Syarfaini, S. A. (2019). Faktor Risiko Kejadian Anemia Pada Ibu Hamil Di Wilayah Kerja Puskesmas Sudiang Raya Kota Makassar. Al-Shihah : Public Health Science Journal, 143-155. 